\title{
Performance and Reliability of Westinghouse's Air Electrode Supported Solid Oxide Fuel Cell at Atmospheric and Elevated Pressures
}

\author{
Norman F. BESSETTE* and Raymond A. GEORGE \\ Received December 18, 1995 ; Accepted March 15, 1996
}

\begin{abstract}
The state-of-the-art solid oxide fuel cell called the air electrode supported-solid oxide fuel cell (AESSOFC), developed by Westinghouse, has shown substantially improved performance and reliability over the previous zirconia porous support tube (PST) design. This latest generation of cells has demonstrated the ability to thermally cycle over 100 times without any performance loss. The AES-SOFC has also demonstrated the ability to operate in cell bundles $(3 \times 6)$ under generator conditions for over 6300 hours without any performance degradation. The number of Electrochemical Vapor Deposition (EVD) steps used in the manufacturing of AES-SOFCs has been reduced from three to two in production and from three to one in the laboratory resulting in significant manufacturing cost reductions. The focus of this paper is to describe the performance and reliability of this latest generation of cells under a variety of generator operating conditions.
\end{abstract}

\section{INTRODUCTION}

Solid oxide fuel cells (SOFCs) are one of the most promising means for direct conversion of chemical to electrical energy and, with their high electrical efficiency and high temperature waste heat, are ideally suited for cogeneration or gas/steam combined cycle applications. SOFC power systems, with their modularity and low emissions, are suitable over a broad range of applications from on-site $(>500 \mathrm{kWe})$ to distributed power $(<50 \mathrm{MWe})$ to central power applications. The Westinghouse cylindrical SOFC has undergone much development in the recent years resulting in increased power output, improved reliability, high efficiency, and extremely low levels of performance degradation placing them on the verge of commercialization. This paper will describe these enhancements and detail how they place air electrode supported-SOFCs (AES-SOFCs) in a position to become the power generation system of choice over the next ten years.

\subsection{Cell Evolution}

In the early stages of cylindrical SOFC development, the cell was built using a porous zirconia support tube as the foundation for the other layers. Due to the diffusion limitations of oxygen through this structure, the power levels remained low and costs high due to the three electrochemical vapor deposition (EVD) processing steps. In the 1987 time frame, the porous support tube was decreased in thickness from what was known as the thick porous support tube (thick PST) to a thin porous support tube (thin PST). This change increased the power

\footnotetext{
Westinghouse Electric Corp., Science \&

Technology Center, 1310 Beulah Road, Pittsburgh,

PA 15235, USA.
}

Key Words: Air Electrode Supported, Pressure, Power, Reliability. density levels by nearly $50 \%$ but still required excessive manufacturing steps and costs.

In the early 1990's, the shift was made from an SOFC built on a porous zirconia tube to one supported by the air electrode itself. This shift resulted in a power density increase of about $33 \%$ over the thin PST cell due to a decrease in diffusion limitations and resulted in the elimination of one cell component. During the development of this AES-SOFC process, development of the doped lanthanum chromite interconnection and nickel cermet fuel electrode have allowed these materials to be manufactured by nonEVD processes. The interconnection was the first layer applied by a non-EVD process and is now plasma sprayed as part of standard cell production resulting in a two EVD step cell. The second layer applied by nonEVD processing was the fuel electrode. This non-EVD process has been successfully demonstrated in the laboratory and is currently being scaled up for standard cell production. The removal of two EVD steps from the AES-SOFC manufacturing process results in a more cost effective product without compromising life or reliability ${ }^{1)}$. Table 1 shows the cell design evolution. It should be noted that all results presented are for cells operating on hydrogen/water fuel at $85 \%$ fuel utilization and six times the stoichiometric air flow unless otherwise stated.

Along with the increase in power density, the cell length was scaled up from 30 to $150 \mathrm{~cm}$ in active length resulting in increased power output per cell. At one atmosphere pressure, AES-SOFCs of $150 \mathrm{~cm}$ active length have demonstrated power levels of 210 watts per cell compared to 20 watts for the original 30 $\mathrm{cm}$ thick-PST or 64 watts for a $50 \mathrm{~cm}$ AES cell. This $230 \%$ increase in cell power of the $150 \mathrm{~cm}$ active length cell over the $50 \mathrm{~cm}$ cell results in less cells to be manufactured and major cost reductions per kilowatt of electricity. Figure 1 shows the increases in cell power 
as well as the analytical prediction for $150 \mathrm{~cm}$ length cells at 10 atmospheres.

To date, Westinghouse has manufactured well over a thousand $50 \mathrm{~cm}$ AES-SOFCs at its Pre-Pilot Manufacturing Facility (PPMF) and will begin producing $150 \mathrm{~cm}$ cells at its new Pilot Manufacturing Facility (PMF) in early 1996. Of the AES cells manufactured, hundreds have been electrically tested as

Table 1 Cell Design Evolution from PST Cells to AES Cells.

\begin{tabular}{|l|l|l|l|l|l|l|l|}
\hline Year & $\begin{array}{l}1983 \\
87\end{array}$ & $\begin{array}{l}1987 \\
-89\end{array}$ & 1990 & 1991 & 1993 & 1994 & 1995 \\
\hline $\begin{array}{l}\text { Cell } \\
\text { Type }\end{array}$ & $\begin{array}{l}\text { Thick } \\
\text { PST }\end{array}$ & $\begin{array}{l}\text { Thin } \\
\text { PST }\end{array}$ & AES & AES & AES & AES & AES \\
\hline $\begin{array}{l}\text { Cell } \\
\text { I.D } \\
\text { (mm) }\end{array}$ & 8.9 & 10.4 & 11.8 & 11.8 & 11.8 & 11.8 & 17.6 \\
\hline $\begin{array}{l}\text { Cell } \\
\text { O.D } \\
\text { (mm) }\end{array}$ & 15.2 & 15.9 & 15.9 & 15.9 & 15.9 & 15.9 & 22.3 \\
\hline $\begin{array}{l}\text { PST } \\
\text { Thk } \\
\text { (mm) }\end{array}$ & 2.0 & 1.2 & 0.0 & 0.0 & 0.0 & 0.0 & 0.0 \\
\hline $\begin{array}{l}\text { AE Thk } \\
\text { (mm) }\end{array}$ & 1.0 & 1.4 & 1.9 & 1.9 & 1.9 & 1.9 & 2.2 \\
\hline $\begin{array}{l}\text { Cell } \\
\text { Length } \\
\text { (cm) }\end{array}$ & 30, & 50 & 50 & 50 & 50 & 100 & 150 \\
\hline $\begin{array}{l}\text { Peak } \\
\text { Cell } \\
\text { Power } \\
\text { (W) }\end{array}$ & $20-24$ & 48 & 64 & 64 & 64 & 127 & 210 \\
\hline $\begin{array}{l}\text { EVD } \\
\text { Steps }\end{array}$ & 3 & 3 & 3 & 3 & 2 & 2 & 2 \\
\hline
\end{tabular}

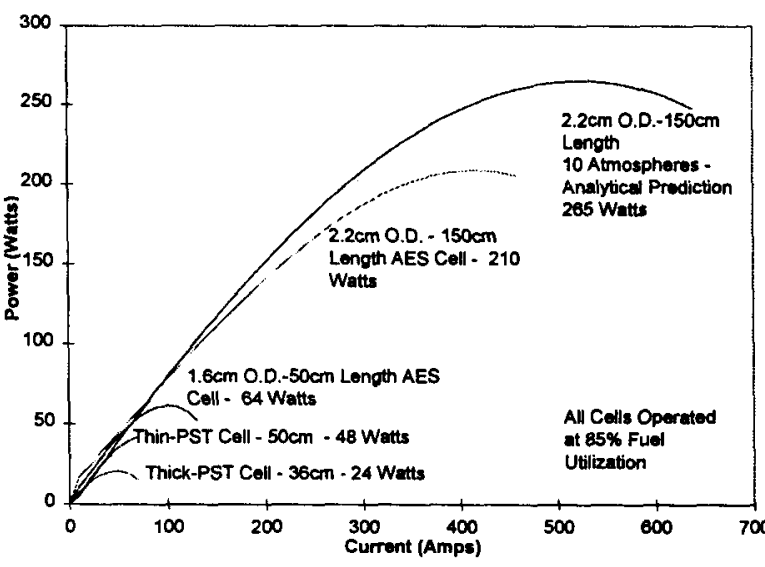

Fig.1 (W) SOFC Power Evolution.

both single cell tests and bundle tests (a $3 \times 6$ bundle) to demonstrate performance and reliability issues such as voltage degradation rate, thermal cycle ability, and operation at a variety of temperatures and pressures.

\subsection{Life and Performance Degradation}

AES-SOFCs have shown the ability to perform for extended periods of time under a variety of operating conditions with little or no performance degradation.
The degradation rate for Westinghouse cylindrical SOFCs has decreased from $0.5-2 \%$ per 1000 hours for PST cells to less than $0.2 \%$ per 1000 hours for AES cells.

Figure 2 shows the longest running SOFC manufactured with a thin PST which has operated for over 59,000 hours (6.7 years). These cells have shown a degradation rate of less than $0.5 \%$ per 1000 hours of operation.

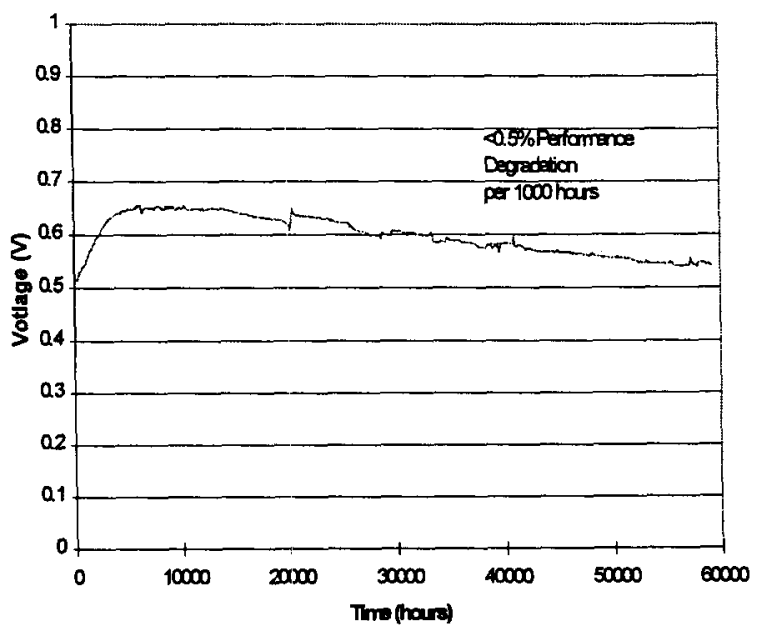

Fig. 2 Performance History of the Longest Operating SOFCs.

AES-SOFC technology development has decreased this degradation rate from $0.5-2 \%$ to less than $0.2 \%$ per 1000 hours with cells of two EVD steps. Figure 3 shows the V-I performance of a $3 \times 6$ bundle of $50 \mathrm{~cm}$ AES-SOFCs processed with two EVD steps after 810 hours and 5065 hours of operation on natural gas under generator conditions. The bundle was operated at a nominal cell temperature of $1000^{\circ} \mathrm{C}$ with a maximum to minimum axial temperature variation of $160^{\circ} \mathrm{C}$ at $85 \%$ fuel utilization and five to six times the stoichiometric oxidant flow.

Both curves show identical performance, to within the accuracy of the PC controlled GENESIS data acquisition system, demonstrating the excellent stability of this generation of cells. Also, between the two sets of V-I measurements, the bundle was deliberately thermal cycled to near room temperature ten times to demonstrate its robustness. 


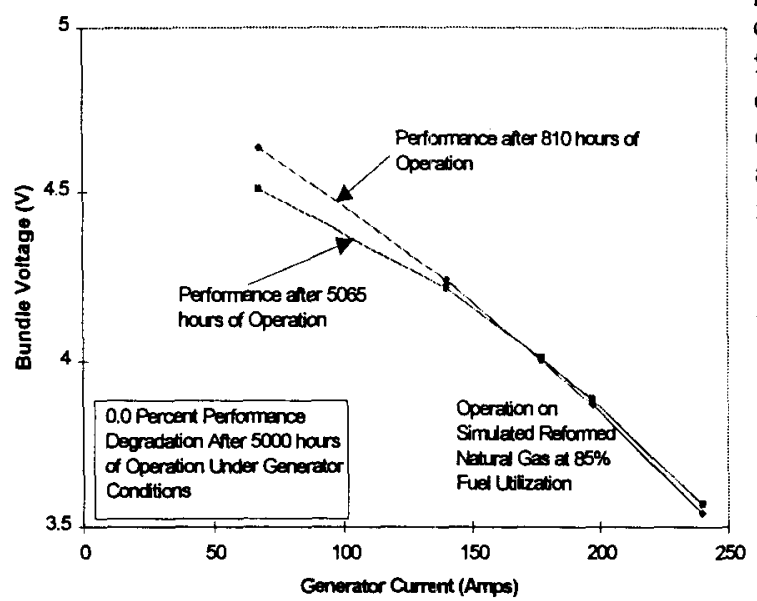

Fig.3 Performance Over Time of an 18 Cell Bundle Test.

\subsection{Reduction of EVD Steps}

Through the reduction of EVD steps, major manufacturing cost reductions can be realized. Fortunately, the electrical performance of cells processed with one EVD step have shown little performance loss over cells processed with two EVD steps. Figure 4 shows the V-J performance of a cell processed with one EVD step versus a cell processed with two EVD steps. performance of the non-EVD fuel electrode is comparable to that of the EVD fuel electrode cell. In fact, the fuel side polarization with a non-EVD fuel electrode is actually better than that of the EVD fuel electrode. This has been proven through electrical test as well as through SEM and EPMA microcharacterization.

To electrically test the fuel side polarization, diagnostic tests are performed where the fuel is diluted with nitrogen in a $1: 1$ and $2: 1$ ratio at fixed current density. This test assesses the concentration polarization of cells versus each other. Table 2 shows the impact on performance of these dilution tests.

Table 2 Comparison of Fuel Side Polarization Between EVD and non-EVD Fuel Electrodes.

\begin{tabular}{|c|c|c|c|}
\hline Cell Type & $\begin{array}{r}\text { Average } \\
\text { EVD Fuel } \\
\text { Electrode } \\
\text { Cell }\end{array}$ & $\begin{array}{r}\text { Non-EVD } \\
\text { Fuel } \\
\text { Electrode- } \\
\text { Cell }\end{array}$ & $\begin{array}{c}\text { Non-EVD } \\
\text { Fuel } \\
\text { Electrode- } \\
\text { Cell 2 }\end{array}$ \\
\hline $\begin{array}{c}1: 1 \\
\text { Dilution }\end{array}$ & $7 \mathrm{mV}$ & $1 \mathrm{mV}$ & $4 \mathrm{mV}$ \\
\hline $\begin{array}{c}2: 1 \\
\text { Dilution }\end{array}$ & $15 \mathrm{mV}$ & $4 \mathrm{mV}$ & $10 \mathrm{mV}$ \\
\hline
\end{tabular}

From Table 2 it is clear that the increased number of active reaction sites results in a $50 \%$ reduction in fuel side polarization of the non-EVD fuel electrode over the EVD fuel electrode.

Figure 5 shows the voltage stability of two AES cells, processed with one EVD step, operated on hydrogen fuel at $450 \mathrm{~mA} / \mathrm{cm}^{2}$ for over 4600 hours.

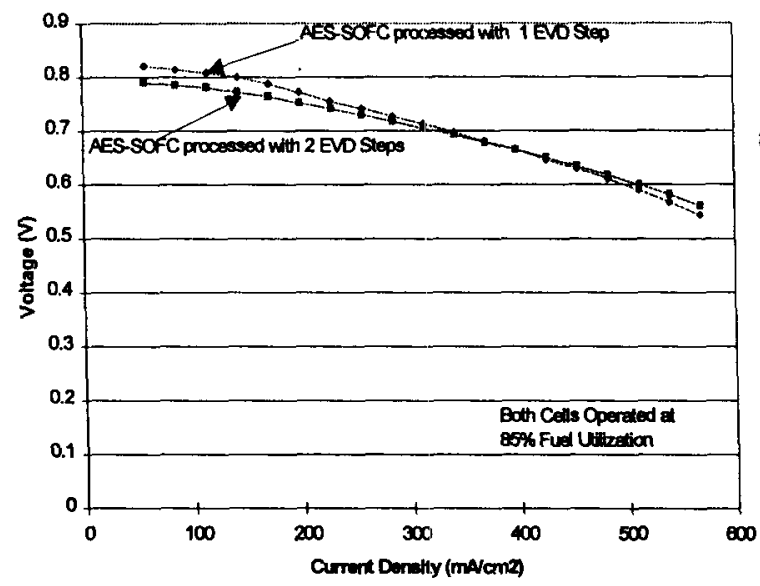

Fig.4 Performance Comparison of AES Cells Processed with One and Two EVD Steps.

Both cells were operated on hydrogen fuel at $85 \%$ fuel utilization. Even at this high fuel utilization, the

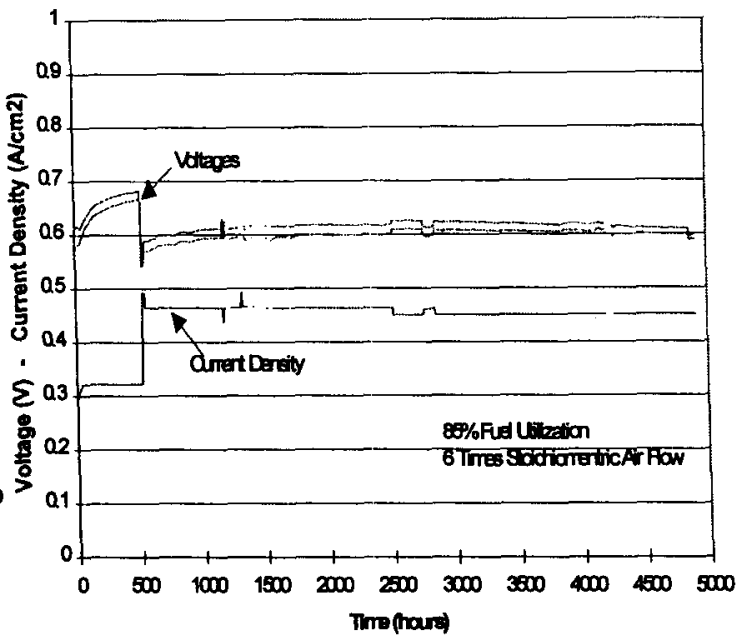

Fig. 5 Performance of Two AES SOFCs Manufactured Using One EVD Step. 
These cells were subjected to nine thermal cycles to less than $300^{\circ} \mathrm{C}$ and ten thermal cycles to $600^{\circ} \mathrm{C}$ over the 4600 hour period of operation with negligible performance loss.

\subsection{Thermal Cycle Ability}

For any SOFC generator to be commercially viable, the unit must be able to sustain thermal cycles to allow for planned or forced outages. The AES-SOFC has shown the ability to thermally cycle to room temperature over 100 times without performance or cell integrity losses as shown in Figure 6. The V-J performance of two cells which had not encountered thermal cycles is very similiar to two cells which have thermally cycled 106 times. Figure 7 shows the number of AES-SOFCs which have been thermally cycled versus the number of cycles experienced.

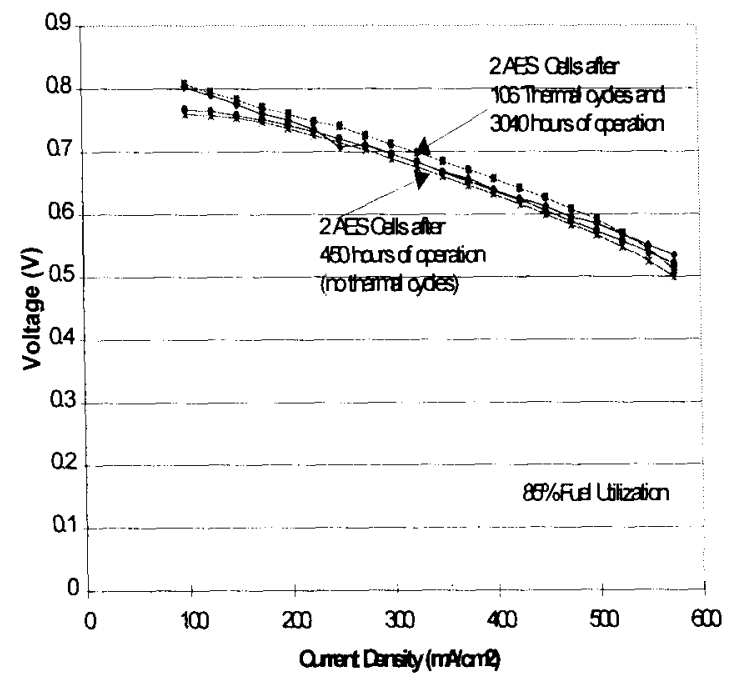

Fig.6 Comparison of AES Cells Before and After 106 Thermal Cycles to Ambient.

The figure shows that out of 363 AES-SOFCs completing between one and 106 thermal cycles to room temperature, only eight have resulted in failure, all of which can be traced to either known pre-existing flaws or erroneous operation. The cells with preexisting flaws, determined from extensive quality control inspection, would not have been acceptable for generator applications.

In addition to the ability to sustain large numbers of thermal cycles, the AES-SOFC has shown the ability to cycle with a rapid temperature ramp rate making them ideal for rapid start-up or restart following a power interruption. The thermal cycles presented above are

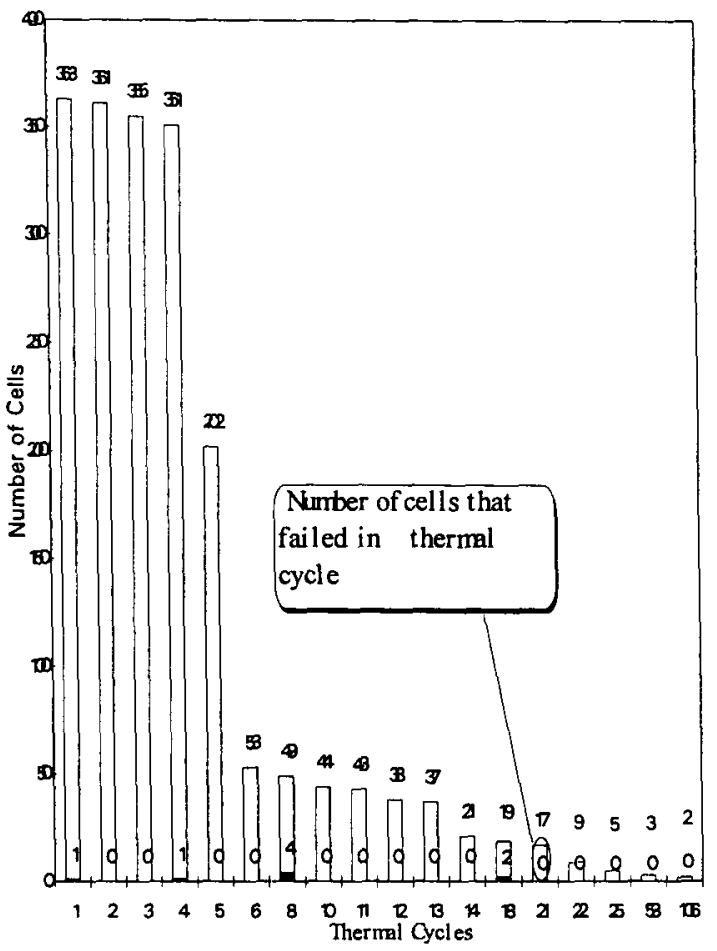

Fig.7 Number of Cells vs. Thermal Cycles for $50 \mathrm{~cm}$ AES Cells.

for temperature ramps from room temperature to $1000^{\circ} \mathrm{C}$ within 5 hours or less. This ramp rate of $200^{\circ} \mathrm{C} / \mathrm{hr}$ would allow a generator to move from a hot standby temperature of $600^{\circ} \mathrm{C}$ to $1000^{\circ} \mathrm{C}$ and full power within 2 hours.

Figure 8 shows a typical quality control thermal cycle endured by selected production cells to verify integrity of cell batches. The plot shows two cycles in temperature to $600^{\circ} \mathrm{C}$ followed by a drop to under $300^{\circ} \mathrm{C}$ with the cells going to open circuit on the decrease in temperature maintaining air on the oxidant side and a reducing environment on the anode side, reloading during the temperature increase above $600^{\circ} \mathrm{C}$ and reaching a current density of $335 \mathrm{~mA} / \mathrm{cm}^{2}$ at $1000^{\circ} \mathrm{C}$. It should be noted that both cells return to their previous operating point after each current reload. 


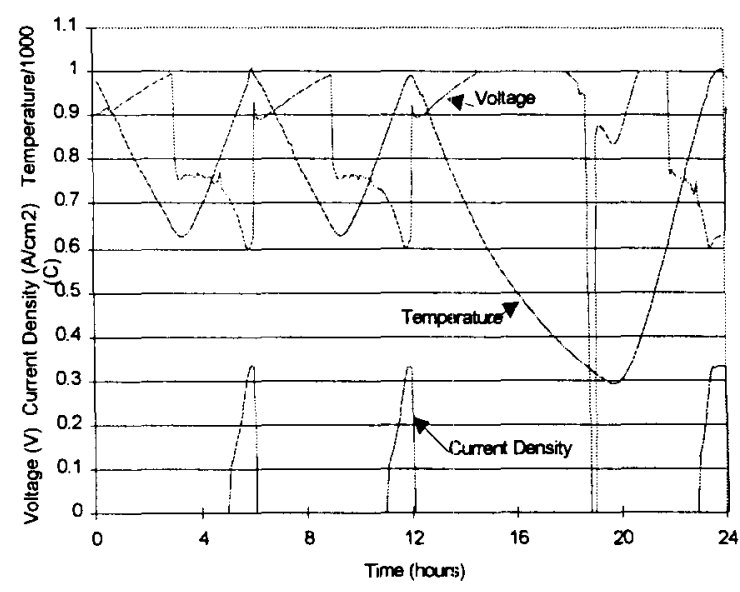

Fig. 8 Response of an AES-SOFC to Rapid Thermal Cycling.

\subsection{Operating Temperature and Temperature} Distribution

One continual problem encountered by many other SOFC designs is the ability to endure large temperature non-uniformities as well as sustain high performance levels at lower operating temperatures. The Westinghouse AES-SOFC, with its seal-less geometry, has solved both of these problems. The existing $50 \mathrm{~cm}$ active length cells have successfully operated with over $150^{\circ} \mathrm{C}$ temperature variation along the axis and with gradients reaching values greater than $5^{\circ} \mathrm{C} / \mathrm{cm}$.

From a performance standpoint, the AES-SOFC at $900^{\circ} \mathrm{C}$ can operate at power levels equal to the thin wall PST cell at $1000^{\circ} \mathrm{C}$. Fig. 9 shows the comparison of a $50 \mathrm{~cm}$ AES cell operating at $900^{\circ} \mathrm{C}$ versus the thinPST cell at $1000^{\circ} \mathrm{C}$.

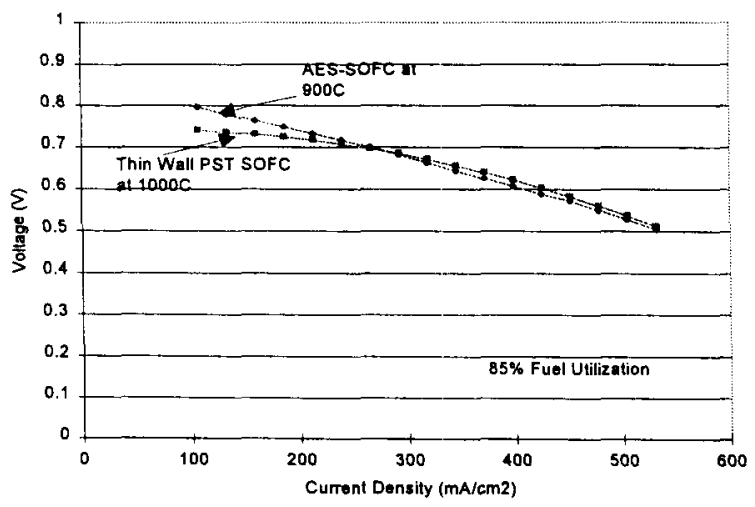

Fig. 9 Comparison of Cell Performance at Different Temperatures.
The AES cell at a lower operating temperature generates the same performance as that of the thin wall PST cell under nominal operating temperature which allows the AES cell to operate at acceptable power levels with a wider temperature range. By allowing for larger axial gradients and a wider temperature range for operation, AES-SOFC generators become easier and less expensive to design bringing them closer to commercialization. A wider operating temperature range also allow for more natural gas reformation to occur directly on the cell without severe performance penalties further simplifying the generator design.

\subsection{Pressurized Performance}

Since early 1994, Westinghouse and Ontario-Hydro Technologies (OHT) have jointly operated a pressurized AES-SOFC test program to determine the merits of SOFC operation at elevated pressure. At elevated pressures, fuel cells achieve higher power levels due to the increased Nernst potential as well as the ability to be utilized as a combustor for gas turbines. To date, Westinghouse and OHT have tested a total of 14 AES-SOFCs for over 6800 hours at pressures from 1 to 15 atmospheres on both hydrogen and natural gas fuel.

Figure 10 shows the comparative V-J curves for an AES-SOFC at 1 and 10 atmospheres operating pressure, respectively.

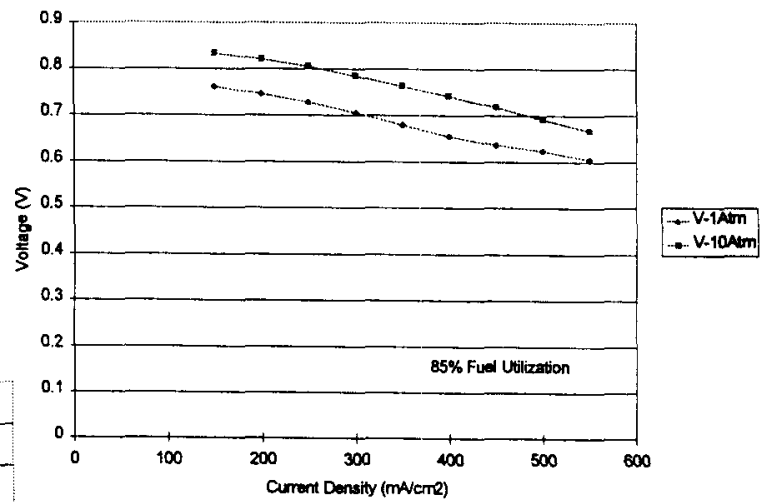

Fig. 10 V-J Performance of AES Cells at 1 and 10 Atmospheres.

The curve shows the increase in voltage to be fairly uniform at each operating point over the 1 atmosphere data. The average shift was $76 \mathrm{mV}$ which is slightly greater than the $63 \mathrm{mV}$ expected based upon changes in Nernst potential. This increased shift could be due to the decreased polarizations on both the oxidant and fuel side or changes in material resistivity at elevated pressures.

Figure 11 shows the resulting power versus current density curve for each operating pressure. 


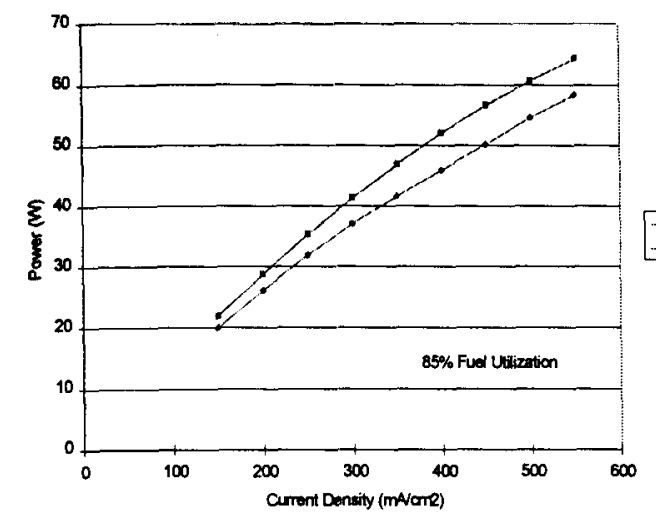

Fig. 11 Power Comparisons at 1 and 10 Atmospheres.

The figure shows that at 10 atmospheres, the $1.59 \mathrm{~cm}$ diameter cell produces $1.29 \mathrm{~W} / \mathrm{cm}$ at $550 \mathrm{~mA} / \mathrm{cm}^{2}$ even though it has not reached maximum power. Extrapolating the V-J curve places the cell at a peak power of $1.46 \mathrm{~W} / \mathrm{cm}$, or $13 \%$ above that of the 1 atmosphere case. By increasing cell power by $13 \%$, the number of cells needed decreases by nearly the same percentage resulting in reduced costs.

AES-SOFCs have also shown the same low degradation rate after operation at elevated pressure levels as those cells operated at atmospheric pressure. Figure 12 shows V-J data taken over a four month period for one of the four cells in a test article which operated for over 5000 hours at various pressures from 1 to 10 atmospheres with a cumulative total of over 1700 hours at 10 atmospheres.

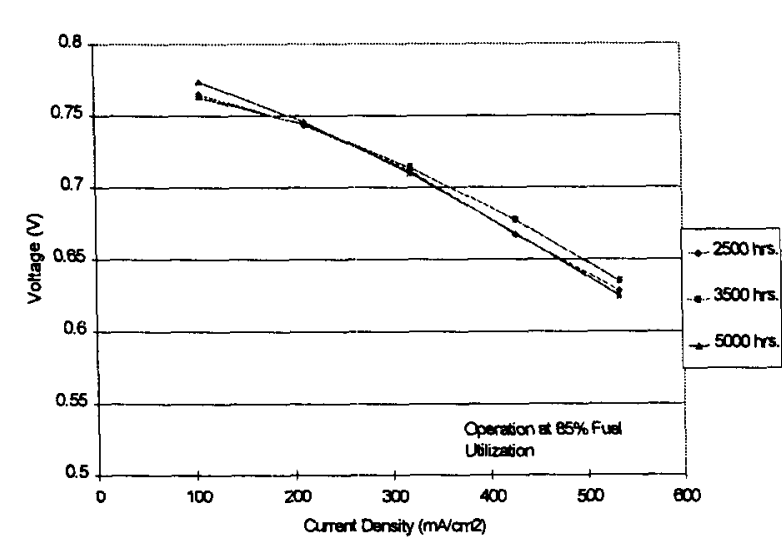

Fig.12 Performance of an AES-SOFC Over 5000 Hours at Different Pressures.
As seen in Figure 12, the three V-J curves are indistinguishable. During this test, the cells also performed multiple thermal cycles down from many different pressures.

\subsection{Bundle Repairability}

Even with the excellent reliability shown by AESSOFCs and the extensive quality control inspection used to avoid placing defective cells into generators, the possibility of a cell failing over the life of a commercial generator exists. In response to this potential problem, Westinghouse has demonstrated a bundle repairability procedure allowing for any number of cells to be replaced with minimal shutdown time. Also, tests of cell bundles have demonstrated that cells adjacent to failed cells show no damage and can be restarted once the failied cells are replaced.

To demonstrate this feature, Westinghouse ran a test containing two $3 \times 6$ cell bundles of which some cells were known to have pre-existing flaws. This test operated on both natural gas and hydrogen for 2000 hours before three defective cells were found to have failed. At this point, the test was shut down and the failed cells were removed from the bundle and replaced with new cells. Though the cells adjacent to the failed cells showed some oxidization of the fuel electrode, they were subsequently reduced upon returning to fuel gas and performed without any sign of permanent degradation. The test was then restarted and ran for an additional 4300 hours.

\subsection{Future Bundle Tests}

Though electrical testing of single cells provides useful information into a cells performance, it does not demonstrate cell performance under actual generator conditions nor can it test generator components prior to module fabrication. Due to these reasons, Westinghouse has tested multiple groupings of cells or 'bundles' as mentioned above. In early 1996, Westinghouse will perform two more bundle tests each containing 48 AES-SOFCs of $150 \mathrm{~cm}$ active length which are prototypic of cells for the first $100 \mathrm{~kW}$ SOFC generator scheduled for delivery to the consortium of Dutch/Danish utilities (EDB/ELSAM) in early 1997. This same cell design will be used in a future "MWe-Class" pressurized SOFC power system. Therefore, the first test will be operated under atmospheric conditions while the second will operate at elevated pressures up to 10 atmospheres.

The first bundle test article contains two $3 \times 8$ bundles and includes internal reformation of natural gas without the need for an expensive external reformer. With this new design, the cell axial temperatures will remain more uniform than in the $20 \mathrm{~kW}$ modules and will operate at lower stoichiometric oxidant flows allowing for less parasitic power as a percentage of total power generated. All of the cells were manufactured with two EVD steps. 
The second bundle test article also contains two $3 \times 8$ bundles and internal reformers which will operate up to 10 atmospheres. This test will demonstrate the performance of commercial prototype cell bundles at elevated pressures as well as identify any generator design concerns. This test, like the atmospheric test, will have cells manufactured with two EVD steps.

\subsection{Quality and Process Control}

To assure that only cells of the highest quality enter into an SOFC generator, Westinghouse has developed an extensive quality and process control procedure. The air electrode tube itself, the foundation of the cell, must pass over 20 diagnostic tests before being accepted into production. Likewise, all other materials used in the production of these cells must pass equally stringent guidelines. Multiple quality control tests are also performed on every cell during production after each production step to assure that each passes the necessary criteria before being accepted into the next process.

During production, to assure the highest quality of fuel cells, multiple finished cells are removed for extensive testing. Some cells are removed for microcharacterization studies to assure cell and component integrity. Other cells are randomly removed from production on a specified sampling plan to electrically test. The cells electrically tested must meet predefined minimum performance levels as well as an extensive thermal cycling plan considered more severe than what would be encountered in generator operation. Also, some cells are grouped into bundles and operated under generator conditions to assure proper operation under real conditions as well as demonstrate the functionality and integrity of generator components.

\section{CONCLUSION}

The Westinghouse AES-SOFC has shown excellent performance improvements over previous cylindrical designs as well as unmatched reliability and minimal degradation placing it in a position to be a viable option in the commercial power generation market. Cells extensively thermal cycled show no noticeable decrease in performance and voltage degradation rates for cells operating between 1 and 10 atmospheres are close to $0 \%$ for operating times up to 6000 hours. With the demonstrated repairability of bundles as well as extensive quality control, generator unavailability can be minimized providing clean, efficient, sustainable power. With the reduction in EVD steps and scale-up of cell power resulting in a reduced number of cells needed, substantial costs savings are developing which will allow the Westinghouse SOFC generator to be a cost competitive power producer before the end of the century.

The development of the Westinghouse tubular solid oxide fuel cell (SOFC) has been supported by the
United States Department of Energy (DOE), Morgantown Energy Technology Center (METC) under a cooperative agreement, contract number DEFC21-91MC28055.

The pressurized SOFC testing effort is supported by: The United States Department of Energy (DOE), Morgantown Energy Technology Center (METC), Westinghouse; Ontario Hydro Technologies (OHT) and their Canadian funding partners [the Canadian Electrical Association, Natural Resources Canada, Gas Technology Canada, Consumers Gas, British Gas, Union Gas, and the Ontario Ministry of Environment and Energy]. In addition, analysis and interpretation of data is sponsored by the preceding plus the New Energy and Industrial Development Technology Organization (NEDO) of Japan and their participating Japanese Electric Power Companies [Hokkaido Electric Power Company, Tokyo Electric Power Company, Chubu Electric Power Company, Chugoku Electric Power Company, Kyushu Electric Power Company, and the Electric Power Development Corporation].

\section{REFERENCES}

1) S.C. Singhal, Proceedings of the Fourth International Symposium on Solid Oxide Fuel Cells, The Electrochemcial Society, 195, (1995) 